\title{
TOPONIMIA, TERRITORIO Y ESPACIOS DE LA VILLA DE CASTIELFABIB (REINO DE VALENCIA, SIGLOS XII-XV) ${ }^{1}$
}

\author{
TOPONYMY, TERRITORY AND SPACES \\ OF THE TOWN OF CASTIELFABIB \\ (KINGDOM OF VALENCIA, $12^{\text {TH }}-15^{\text {TH }}$ CENTURIES)
}

\author{
Alberto-Jesús MARTíNEZ BEDMAR \\ Universidad de Barcelona \\ amartibe30@alumnes.ub.edu
}

\begin{abstract}
Resumen: El presente artículo estudia la toponimia medieval del término, huerta y villa de Castielfabib. Para ello se realiza un trabajo inicial de identificación y relación de los diversos espacios con la actualidad; en segundo término, se estudia el uso del territorio y las actividades laborales desarrolladas en el medio rural $\mathrm{y}$ en la villa. Finalmente, se ha tratado de realizar una aproximación a la fisionomía de la villa a través de los elementos documentados con el objetivo de lograr una reconstrucción hipotética de diversos elementos definitorios como son la Casa de la Villa y el recinto fortificado.
\end{abstract}

Palabras clave: toponimia, territorio, espacios; Castielfabib, siglos XII-XV, reino de Valencia.
Abstract: This paper studies the medieval toponymy of the term, orchard and town of Castielfabib. For this, an initial work of identification and relation of the various spaces is carried out; secondly, the use of the territory and the work activities carried out in rural areas and in the town are studied. Finally, it is had tried to make an approach to the physiognomy of the town through the documented elements with the aim of achieving a hypothetical reconstruction of various defining elements, such as the Casa de la Villa (House of the Town) and the fortified enclosure.

Keywords: toponymy, territory, spaces; Castielfabib, $12^{\text {th }}-15^{\text {th }}$ centuries, kingdom of Valencia.

1 Este artículo se inscribe en las actividades del proyecto El notariado público en el Mediterráneo Occidental. Escritura, instituciones, sociedad y economía (siglos XIII-XV) (Ministerio de Ciencia e Innovación. PID2019-105072GB-I00). 


\section{Introducción ${ }^{2}$}

La villa de Castielfabib es una población ubicada en el poniente valenciano, de temprana conquista cristiana en 1210, y en tierra de frontera entre el reino de Valencia y los reinos de Aragón y Castilla. Por ese motivo, fue un territorio codiciado por los castellanos y un lugar de enfrentamientos bélicos con el que fue, durante gran parte del periodo medieval, el enemigo del oeste. La ubicación en esta encrucijada geográfica aportó a la villa dinamismo económico y social, así como riqueza, llegando a ser una pequeña urbe próspera durante los siglos bajomedievales. Sin embargo, la unión de la corona de Aragón con la castellana quitó parte del poder estratégico de la zona, trasladando el centro de poder a la vecina localidad de Ademuz, y sumiendo a Castielfabib en una decadencia que se prolongó hasta finales del siglo XVIII. En este momento se inició una expansión demográfica sin precedentes en la comarca, que condujo a una transformación del paisaje con la roturación de nuevas tierras para cultivo en zonas donde antes se extendían bosques. Este proceso se extendió durante algo más de siglo y medio, hasta inicios del siglo XX. A partir de entonces comenzaron los procesos de emigración de sus gentes hacia ciudades y lugares más prósperos, y parte de las tierras de labor fueron reforestadas. Este conjunto de procesos históricos ha dado lugar en la actualidad a un panorama de despoblación, en el que el paisaje original medieval se conserva ciertamente mermado debido al abandono de las tierras de cultivo y a las intervenciones que tuvieron lugar en el entorno en los dos últimos siglos.

En este contexto, el presente trabajo pretende aproximarse a lo que fue la villa y término de Castielfabib con el objetivo, en primer lugar, de ubicar los topónimos que aparecen en la documentación escrita medieval y, en segundo término, de identificar si han perdurado, mutado o, en el peor de los casos, se han perdido definitivamente; en este supuesto, el intento de identificación se trata de realizar a partir del conjunto de referencias que aparecen documentadas junto a un determinado topónimo actualmente inexistente. Además del interés por realizar una enumeración lo más extensa posible de la toponimia medieval relativa a la villa y término de Castielfabib, se ha abordado la tarea de elaborar diferentes mapas que ayuden a su ubicación. Estos objetivos iniciales se complementan, por un lado, con la aproximación

2 Abreviaturas utilizadas: $\mathrm{ACA}=$ Archivo de la Corona de Aragón; AHN=Archivo Histórico Nacional; AHPT=Archivo Histórico Provincial de Teruel; ARCSCCV=Archivo del Real Colegio-Seminario de Corpus Christi de Valencia; ARV=Archivo del Reino de Valencia. 


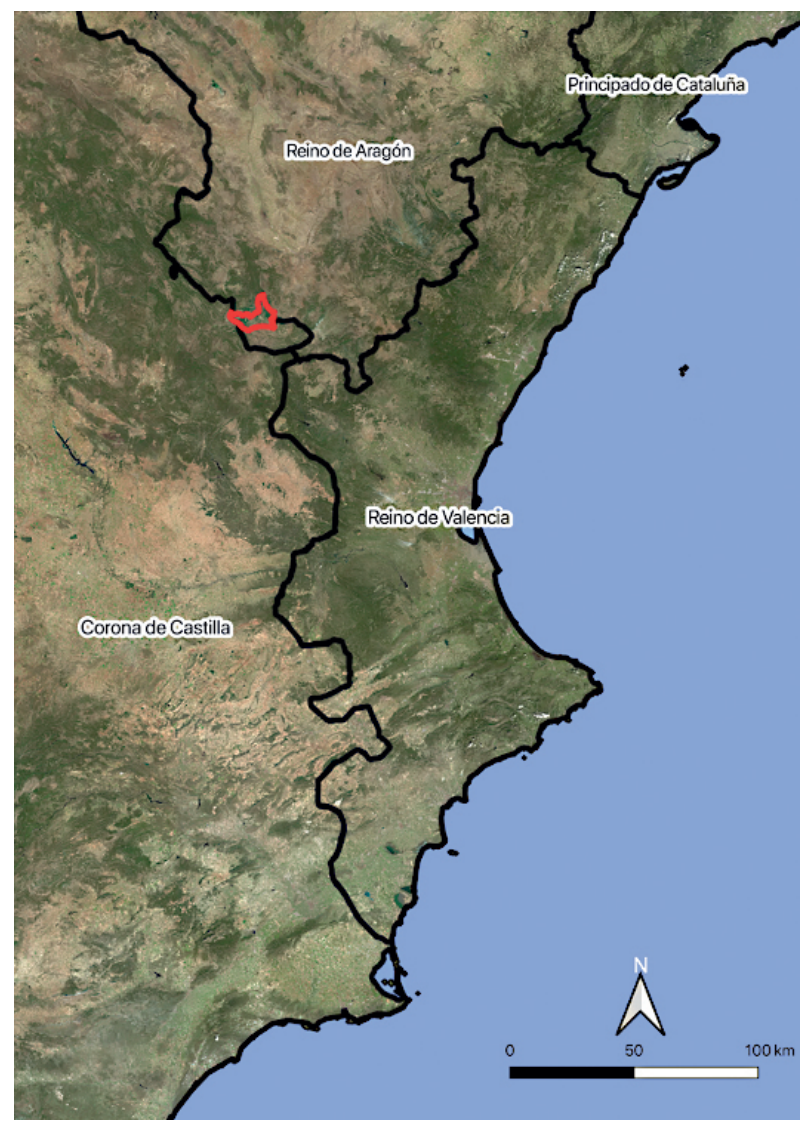

Mapa 1: Ubicación de la villa de Castielfabib. Elaboración propia. ${ }^{3}$

a los diversos usos de la tierra y al conocimiento de la tipología y extensión de las explotaciones de este medio natural; y, por otro lado, con una aproximación a la fisionomía de la villa a través de la identificación de diferentes espacios habitacionales y laborales en el plano urbano, en especial, distintos obradores. En su conjunto, el trabajo pretende hacer una aproximación a la realidad de la población de Castielfabib y su término desde diversas perspectivas.

3 Todos los mapas has sido elaborador con el programa QGIS 3.10, y se ha utilizado de base las ortofotografías del PNOA (Plan Nacional de Ortofotografía Aérea), del Instituto Geográfico Nacional. 


\section{Fuentes}

Para poder llevar a cabo la presente investigación se han utilizado básicamente fuentes primarias, publicadas e inéditas, además de las fuentes secundarias que posibilitan la contextualización y el estudio del tema abordado en perspectiva comparada.

No contamos con fuentes locales propias debido a que la documentación municipal y eclesiástica fue destruida en el transcurso de las últimas guerras civiles; y se desconoce la existencia de archivos patrimoniales o particulares que se remonten a tiempos medievales y que pudieran aportar información documental sobre el término de Castielfabib. No obstante, la documentación real y notarial (la cual, al estar producida en la misma localidad, es la más interesante para esta investigación) constituyen fuentes archivísticas fundamentales para este trabajo. Se han consultado diversos archivos en Madrid, Barcelona, Valencia y Teruel cuyos fondos conservan documentos relativos a la villa — siendo este el caso de la documentación real - o producidos en ella — documentación notarial, fundamentalmente-.

Las primeras referencias a topónimos de dentro del término de la villa de Castielfabib aparecen en la carta de población de Villel (Teruel) concedida por el rey aragonés Alfonso el Casto, y fechada en el año 1180, donde se delimita su término (Ledesma, 1986: 457). ${ }^{4}$ El territorio de esta población aragonesa confrontaba con la villa valenciana por su parte nororiental.

En las siguientes dos centurias las referencias de interés para la presente investigación son escasas limitándose a menciones en los registros de la Cancillería Real, conservados en el Archivo de la Corona de Aragón y a las series de cartas reales del mismo archivo. También hay que destacar el documento de donación por parte de Pedro el Católico de la iglesia de Castielfabib a la Orden del Hospital, donde se mencionan unos términos para la construcción de una iglesia y oratorios (Alvira, 2010: 1128-1129). ${ }^{5}$

Del siglo XV se han conservado un mayor número de documentos, incrementando también el total de topónimos localizados. A ello ha contribuido la conservación de tres manuales notariales producidos en Castielfabib en los

4 AHN, Órdenes Militares, Orden del Temple, Cartulario Magno I, p. 152, núm. 144.

5 Ibídem, Orden de San Juan de Jerusalén, Castellanía de Amposta, carp. 583, núm. 740. 
años $1425,{ }^{6} 1465^{7}$ y entre 1468 y $1470,{ }^{8}$ por el notario Pere Vicent (Andrés, 1990: 603), ${ }^{9}$ y actualmente conservados en el Archivo del Real Colegio-Seminario de Corpus Christi de Valencia. También son de interés las diversas series conservadas en el Archivo del Reino de Valencia, donde hay que destacar un libro de cuentas de las obras del castillo de Castielfabib fechado entre los años 1452 y $1458 .{ }^{10}$ Además, se ha localizado un pergamino producido en la villa en el Archivo Histórico Provincial de Teruel que contiene datos relativos a la toponimia de la alquería de Torrebaja, minúscula porción del término de Castielfabib, constituida en señorío desde principios del siglo XIV. ${ }^{11}$

Finalmente se debe indicar que las menciones extraídas de la documentación consultada se han tratado de identificar utilizando el Nomenclàtor Toponímic Valencià del Institut Cartogràfic Valencià y el Catastro. Asimismo, se ha recurrido a fuentes orales para tratar de identificar topónimos poco usados o no habituales y para los microtopónimos que citan las fuentes escritas.

\section{El término de Castielfabib}

El estudio realizado se estructura en tres apartados en los que, sucesivamente, presentamos la toponimia del término de Castielfabib, la relativa al eje fluvial del río Ebrón (tierras de huerta y regadío), y la propia villa. Se ha utilizado esta distinción por ser la que se encuentra en la documentación histórica que marca la diferencia entre termini dicte ville,$^{12}$ orta dicte ville ${ }^{13}$ e intus dictam villam. ${ }^{14}$

Castielfabib se ubica al noroeste de la actual provincia de Valencia, en el corredor fluvial del Turia, que no siempre se corresponde con el cauce principal del río. Por motivos de asentamiento defensivo o poblacional, grandes lo-

6 ARCSCCV, Protocolos, Pere Vicent, núm. 24.258. Acerca de este manual existe un artículo breve que, de manera divulgadora, pretende conocer la vida en la villa de Castielfabib durante ese año (Rueda, 2001: 27-31). También existe una edición crítica de cuatro documentos de dicho libro (Martínez Bedmar, 2019b).

7 Ibídem, núm. 24.259.

8 Ibídem, núm. 28.718.

9 Acerca del notariado en la villa de Castielfabib: Martínez, 2019c. Acerca del notario Pere Vicent: Cruselles, 1998: 212-213; 227-228; 381; 387.

10 ARV, Mestre Racional, núm. 9.262.

11 AHPT, Concejo, Pergamino Ca, 8, 266 (7 de enero de 1489).

12 ARCSCCV, Protocolos, Pere Vicent, núm. 24.258: 28 de enero de 1425.

13 Ibidem: 2 de abril de 1425.

14 Ibídem: 10 de enero de 1425. 


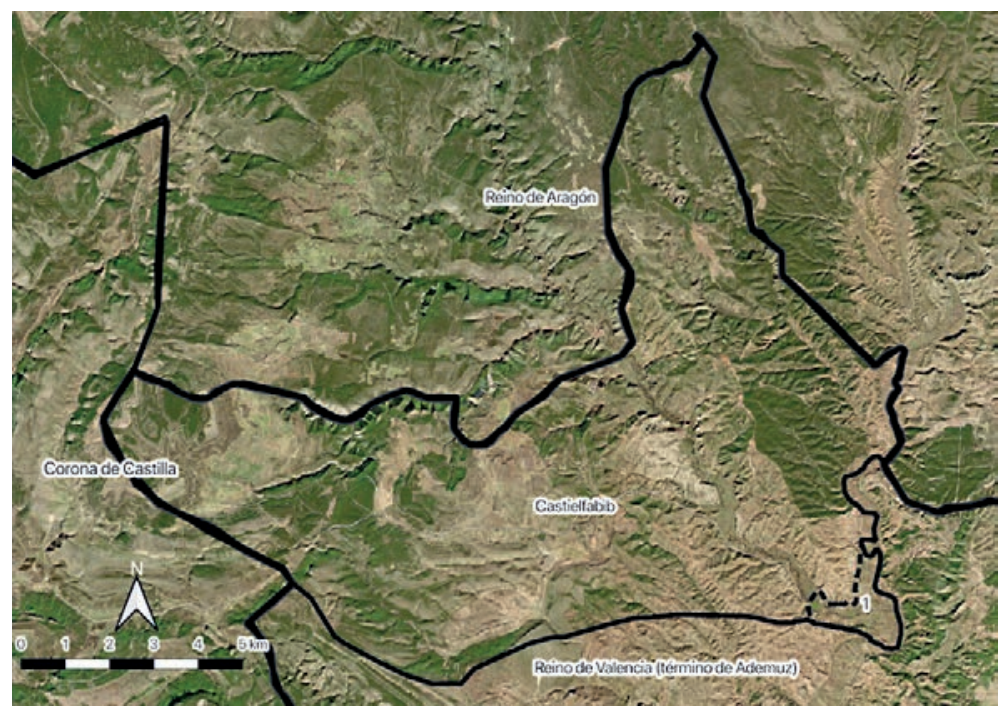

Mapa 2: Ubicación de la villa de Castielfabib, cerca del límite trifinio entre los reinos de Aragón, Valencia y Castilla. 1: Señorío de Torrebaja dentro del término de Castielfabib. Elaboración propia.

calidades como Castielfabib o Alpuente se ubicaron, respectivamente, sobre un afluente del Turia - el río Ebrón - o en un barranco denominado Reguero (Vázquez-Esparza, 2015: 462). El término general de la villa tenía unos 110,3 $\mathrm{km}^{2}$, de los cuales unos escasos $2,2 \mathrm{~km}^{2}$ corresponden al señorío donde se ubicó la alquería de Torrebaja.

El territorio de Castielfabib se encuentra delimitado por el este con el río Turia, que siempre aparece citado en la documentación consultada como Guadalaviar, ${ }^{15}$ un topónimo árabe cuya etimología responde a wadi al-abyad, 'río blanco'. A pesar de ello, el término de ésta se estructura en torno al río Ebrón, afluente del Turia.

Por la parte oriental se han documentado las primeras referencias a topónimos de esta población gracias a la carta de población de Villel de 1180. En la

15 La primera mención al río Turia en el término de la villa de Castielfabib corresponde a la carta de población de Villel, donde uno de los límites es el río Godalaviar (Ledesma, 1986: 457). A lo largo del siglo XV se encuentran numerosas referencias a este río ya sea en tierras de Castielfabib o Ademuz. ARCSCCV, Protocolos, Pere Vicent, núm. 24.258: 20 de mayo y 25 de agosto de 1425; núm. 24.259: 9 de mayo de $1468 ; 13$ de junio de 1469; 5 de febrero de 1470. 


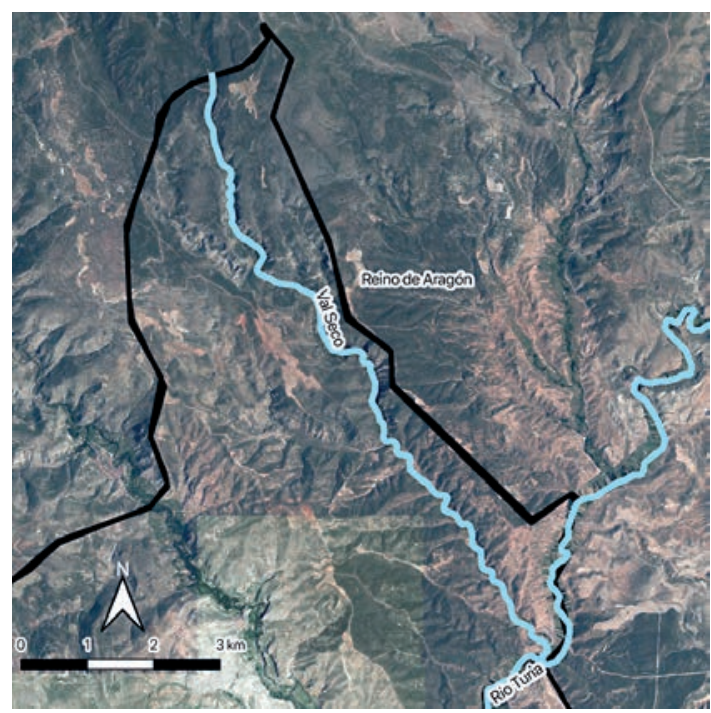

Mapa 3: Ubicación del Val Seco y el río de Molas en la parte oriental del término de Castielfabib, paralelo al límite con el reino de Aragón. Elaboración propia.

delimitación de los términos se hace mención a una parte que treinta años después, se incorporó al alfoz de la villa de Castielfabib. El documento dice:

[...] prende el cerro et da en el camino que va a Tormon, et del camino de Tormon fiere a la fuent de la Penyella et de la fuent de la Penyella fiere en Val Seco et de Val Seco fiere a rio de Molas et de rio de Molas aiuso fiere en Godalaviar (sic) et de Guadalaviar rio den a suso a fuent de Val Lubresco a suso [...] (Ledesma, 1986: 457).

Sobre los topónimos de Val Seco y rio de Molas citados en esta carta, el primero aún se conserva en Castielfabib, aunque la identificación actual no parece corresponder con la aquí referida, ya que no llega a la altura del camino de Tormón. No obstante, hay otro barranco, actualmente llamado Val del Agua, que podría coincidir con el Val Seco de este documento. En cuanto al río de Molas no se conoce ningún topónimo actual con esa denominación, aunque bien pudiera hacer referencia al tramo final del Val del Agua, también conocido como rambla de San Sebastián, que rinde sus aguas al río Turia. La hipótesis de que el Val Seco y el río de Molas sean topónimos que pueden corresponder con el barranco del Val del Agua de la documentación cobra 
fuerza al comprobar que este barranco discurre paralelo al actual límite fronterizo provincial.

Las siguientes referencias relativas al término de Castielfabib son de su parte occidental, zona fronteriza con Castilla, y donde se ubica la actual aldea de Arroyo Cerezo. Las primeras referencias documentales a esta aldea se sitúan en los días previos a la capitulación de Castielfabib, en agosto de 1210, cuando el rey Pedro el Católico hace donación a García Romeu del castillo y villa de El Cuervo, recién conquistados, y fija sus límites, haciéndose mención al Rubeo de Cireso (Alvira, 2010: 1125-1126). ${ }^{16}$ Después, a finales del mes de septiembre de 1270, se vuelve a nombrar un territorio llamado Cireso, en los confines con la vecina Moya (Guinot, 1995: 63). ${ }^{17}$ Ya en el siglo XV aparecen numerosas referencias a dicho territorio con los nombres de el Royo del Cereso, ${ }^{18}$ el Royo del Cereço, ${ }^{19}$ o simplemente el Royo, ${ }^{20}$ topónimo que aún se utiliza popularmente para referirse a este enclave, y que no es más que una traducción del topónimo primigenio Rubeo. La aldea tuvo una importante dedicación a la explotación maderera cuya producción se conducía hasta la vecina Ademuz para transportarla por el río Turia hasta la ciudad de Valencia. ${ }^{21}$ Su característica de poblamiento disperso aún se conserva, a pesar de presentar algunas agrupaciones; los instrumentos notariales se refieren al mansum vocatum de Johan Cit, ${ }^{22}$ a la domus Petri Cit $^{23}$ y a un «mas», sin ningún otro apelativo, en dicho territorio. ${ }^{24}$

En las proximidades de esta aldea se encuentra una corriente de agua, que aparece en la documentación como rivulum sive Regajo del Royo del Cereso, ${ }^{25}$ conservándose en la actualidad la denominación de Regajo. Al oeste de la población se documenta la molam del Cireso ${ }^{26}$ o Muela 'l Cereso (Muela del Cerezo), ${ }^{27}$

16 AHN, Órdenes Militares, San Juan del Hospital, Castellanía de Amposta, carp. 583, núm. 73.

17 ACA, Cancillería, Registros, núm. 16, fol. 212r.

18 ARCSCCV, Protocolos, Pere Vicent, núm. 24.258: 5 de abril y 25 de agosto de 1425.

19 Ibídem, núm. 24.259: 9 de enero de 1470.

20 Ibídem, núm. 24.258: 25 de agosto de 1425. Ibídem, núm. 24.259, docs. 26 de junio de 1469; 29 de septiembre de 1468 .

21 Acerca del comercio maderero con el reino de Valencia: Arciniega, 2011: 99-134. Sobre el oficio del trasporte de la madera a través del medio fluvial (los gancheros): Mileto, 2008: 67-72; 98-101.

22 ARCSCCV, Protocolos, Pere Vicent, núm. 24.258: 20 de mayo de 1425.

23 Ibídem, núm. 24.258: 25 de agosto de 1425.

24 Ibídem, núm. 24.259: 9 de enero de 1470.

25 Ibídem, núm. 24.258, doc. 20 de mayo de 1425.

26 AHN, Órdenes Militares, San Juan del Hospital, Castellanía de Amposta, carp. 583, núm. 73.

27 ARCSCCV, Protocolos, Pere Vicent, núm. 24.259: 17 de enero de 1470. 
paraje próximo al límite con los reinos de Aragón y Castilla que estuvo habitado en 1470, ya que el documento de referencia habla de unas casas en el lugar. También en esta parte de poniente se ha localizado el nombre de la Torreziella del Royo ${ }^{28}$ que podría corresponder con el actual Castillejo de Arroyo Cerezo.

Al este de esta localidad se ubican los nombres de la partida de la Vacariza, ${ }^{29}$ la Colomuela de la Nava ${ }^{30}$ y la Canyada don Ferrando ${ }^{31}$ si bien estos dos últimos no se corresponden completamente a topónimos conservados hoy, sí que existen las partidas denominadas de la Nava y de la Cañada.

En la parte occidental del término también se ha podido identificar el mojón de Penyalva ${ }^{32}$ que corresponde al del límite entre los antiguos términos de Castielfabib y Ademuz, por el reino de Valencia, y con el término de Moya, por el reino de Castilla, siendo actualmente el límite entre los municipios de Castielfabib y Vallanca, por el lado valenciano, y Salvacañete, por el castellano.

Se han documentado más topónimos que debieron corresponder al término de la villa de Castielfabib; sin embargo, no han perdurado a través de los siglos y su recuerdo se ha olvidado, imposibilitando su identificación en la actualidad con la documentación consultada. Algunos de estos nombres son la Fuent de las Cuerdas,${ }^{33}$ que limita con las Cordelleras,${ }^{34}$ y la Fuent de las Stacas. ${ }^{35}$

\section{El eje del río Ebrón}

El eje del río Ebrón, con sus doce kilómetros de recorrido dentro del término de Castielfabib, constituye la principal arteria y vía de comunicación de éste. Con sus aguas se riega una frondosa huerta que se extiende desde el límite con el reino de Aragón hasta que dicho río tributa sus aguas al Turia, dentro del territorio del señorío de Torrebaja.

Antes de tratar la toponimia de sus huertas y vegas, se debe estudiar el propio nombre del río, que en los siglos medievales no es mencionado con

28 Ibídem, núm. 24.259: 29 de septiembre de 1470.

29 Ibídem, núm. 28.718: 10 de octubre de 1465.

30 Ibídem, núm. 28.718: 10 de noviembre de 1465.

31 Ibídem, núm. 24.258: 20 de enero de 1425 (mencionando un documento del 15 de junio de 1400).

32 Ibídem, núm. 24.259: 13 de junio de 1469.

33 Ibídem, núm. 24.258: 3 de enero de 1425.

34 Ibidem.

35 ARCSCCV, Protocolos, Pere Vicent, núm. 24.259: 5 de febrero de 1470. 


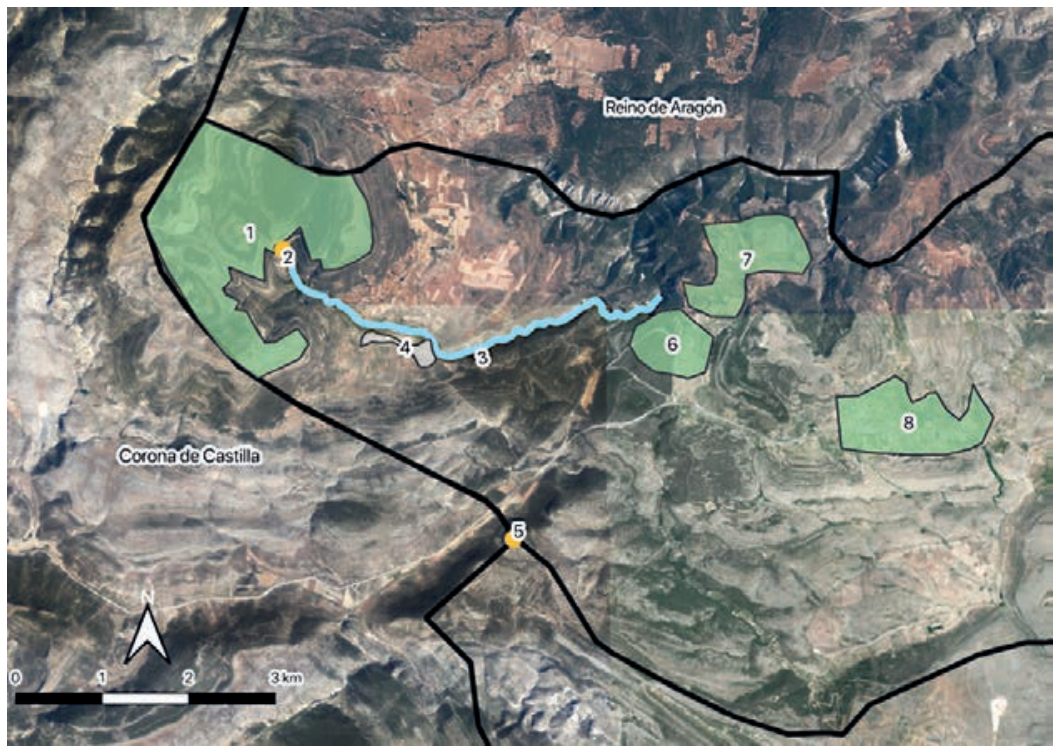

Mapa 4: Ubicación de partidas y lugares de la parte occidental del término de Castielfabib. 1: la Muela'l Cereso; 2: la Torreziella del Royo; 3: el Regajo del Royo del Cereso; 4: el Royo del Cereso; 5: el Mojón de Penyalva; 6: la Vacariza; 7: la Columuela de la Nava (¿2); 8: la Canyada don Ferrando ( $\dot{2}$ ?). Elaboración propia.

el nombre actual. La primera referencia al río Ebrón es coetánea a la conquista cristiana de Castielfabib: ${ }^{36}$ en la donación que Pedro el Católico realiza a la orden del Hospital en 1210 se fijan unos límites para el establecimiento de una iglesia y oratorios y, en las lindes se menciona el flumem nuncupatum Dronio (Alvira, 2010: 1128; Gual, 1953: 209) ${ }^{37}$ Sin embargo, esta denominación no se vuelve a repetir en la documentación medieval, siendo frecuente en el siglo XV que el río Ebrón sea conocido simplemente como el Río. ${ }^{38} \mathrm{Al}$ no existir confusión con otra corriente de agua constante, la denominación se hace por antonomasia, ${ }^{39}$ pudiendo llegar a ser conocido

36 Para saber más de la conquista cristiana de Castielfabib, Martínez Bedmar, 2018: 139-164

37 AHN, Órdenes Militares, Orden de San Juan de Jerusalén, Castellanía de Amposta, carp. 583, núm. 74.

38 ARCSCCV, Protocolos, Pere Vicent, núm. 24.258: 7 de enero, 19 de abril, 20 de abril, 20 de junio, 23 de septiembre, 26 de septiembre y 15 de octubre de 1425; Ibídem, núm. 28.718: 7 de febrero de 1465; Ibídem, núm. 24.259: 24 de junio de 1468; 24 de julio de 1469; y 27 de agosto de 1470.

39 No así ocurre con el otro afluente del Turia en la comarca del Rincón, el Bohilgues, que aparece referenciado por primera vez en el Manual de 1425 del notario castielero Pere Vicent, como el río de 
fuera del término de Castielfabib como el río de Castiel, y así es conocido todavía en la actualidad.

Empezando desde el norte, junto al límite con el reino de Aragón, la primera partida que se encuentra referenciada es la Cuesta del Rato ${ }^{40}$ ubicada en la margen izquierda. Este nombre en nuestros días denomina a la aldea más septentrional del término, que domina desde lo alto una extensa huerta; por ello, se podría pensar que el topónimo que ahora designa este pequeño núcleo poblacional fuera, en origen, el de las tierras que lo circundan y que, lo que en las cronologías documentadas era una casa aislada o una pequeña agrupación de viviendas, fuese el embrión de la futura aldea. En esta zona se encontraba también el lugar llamado el Varranquo Johan de Verne ${ }^{41}$ que no ha podido ser ubicado.

Aguas abajo, en la margen derecha del río Ebrón, se encuentra la partida de regadío de la Penya Negra, ${ }^{42}$ sobre la cual se ha identificado el topónimo de la saxo sive Penya de las Canales, ${ }^{43}$ gracias a las lindes dadas en el documento y al estudio de campo en la zona. Adyacente a estas tierras se encuentra la Vega Somera ${ }^{44}$ nombre que ha mutado en tiempos recientes a Fuente Somera, aunque en la documentación medieval también fue conocida como la Fumela ${ }^{45} \mathrm{o}$ las Pozas. ${ }^{46}$ Este lugar era atravesado por el vallis de la Salobre, ${ }^{47}$ actualmente conocido como la rambla de las Salinas por localizarse allí las salinas de la villa, en explotación hasta finales del siglo XV, cuando se derrumbaron.$^{48}$ Para salvar el desnivel de dicho barranco existió el pontis et canalis vallis de la

Boylgas (ARCSCCV, Protocolos, Pere Vicent, núm 24.258: 3 de abril de 1425). Acerca del topónimo del río Bohilgues, se pueden consultar los trabajos de Antón Andrés (2006) y Martínez Bedmar (2020).

40 ARCSCCV, Protocolos, Pere Vicent, núm. 24.258: 28 de enero de 1425. También aparece mencionado como Cuesta'l Rato en la portada y contraportada interiores del protocolo de 1468-1470 del notario Pere Vicent (Ibídem, núm. 24.259), datado el 13 de agosto de 1435.

41 ARCSCCV, Protocolos, Pere Vicent, núm. 24.259, portada interior (13 de agosto de 1435), donde dice «in partita vulgariter dicta la·Cuesta'l-Rato en·el Varranquo Johan de Verne».

42 Ibídem, núm. 24.258: 11 de abril y 26 de septiembre de 1425.

43 Ibídem, núm. 24.258: 26 de septiembre de 1425.

44 Ibídem, núm. 24.258: 23 de julio y 21 de septiembre de 1425. Ibídem, núm. 24.259: 29 de marzo y 26 de octubre de 1469.

45 Ibídem, núm. 24.259: 29 de marzo de 1469.

46 Ibídem.

47 ARCSCCV, Protocolos, Pere Vicent, núm. 24.258: 23 de julio y 21 de septiembre de 1425.

48 El impuesto sobre las salinas está documentado desde el año 1469 hasta 1488 (ARV, Mestre Racional, núms. $2.282 ; 2.284 ; 2.285 ; 2.286 ; 2.287)$; a partir de esta fecha aparecen como derruides hasta 1494 (Ibídem, núms. 2.288; 2.289; 2.290; 2.291; 2.292; 2.293). 
Salobre, ${ }^{49}$ también conocido como la puent de Salobre, ${ }^{50}$ un puente-acueducto predecesor del actual puente de la rambla de las Salinas, por donde también discurre una acequia.

Continuando por la margen derecha del río Ebrón se llega a la partida de la Barrera,${ }^{51}$ conocida a finales del siglo XV como la Ollería ${ }^{52}$ debido a la presencia de un obrador de este tipo en ese lugar. Próximo a estas tierras se ubica el monasterio de San Agustín, establecido en 1394, aunque no fue hasta principios de la siguiente centuria cuando los monjes se establecieron en esta partida, erigiendo lo que actualmente es el único elemento distinguible del antiguo cenobio, la capilla de Nuestra Señora de Gracia (Eslava, 2014: 92-99). ${ }^{53}$ Próxima al monasterio se situaba la majada de San Agustín —ovilia beati Augustini dicte ville,${ }^{54}$ ovilia sancti Augustini dicte ville-,${ }^{55}$ un espacio dedicado a la guarda de ganado ovino y caprino; esta actividad ganadera parece que constituyó una de las principales actividades económicas para la población de la villa. A continuación de la Barrera está la partida de la Serna,${ }^{56}$; de ella hay que apuntar que, en el contexto de escasez de tierras de cereal en el interior valenciano y de dependencia de la producción aragonesa, en 1425 se localiza en esta zona una parcela sembrada de trigo:

[...] hun huerto de tierra situado en·la Serna, huerta de la dicha villa. Confrontado con tierra de Martín d'Exea, e con tierra de Francischo del Mur. El qual es tenido dius senyoria de·la orden de Muntesa, a cens de [hueco] solidos et a lohismo e fadiga, el qual es sembrado de trigo $[\ldots]^{57}$

A continuación de esta partida se encuentra el paraje llamado el Chorreadero, ${ }^{58} \mathrm{y}$ del que no tenemos más noticia salvo la presencia de una

49 ARCSCCV, Protocolos, Pere Vicent, núm. 24.258: 23 de julio y 21 de septiembre de 1425.

50 Ibídem, núm. 24.259: 26 de octubre de 1469.

51 Ibídem, núm. 24.258: 23 de septiembre de 1425. Ibídem, núm. 28.718: 10 de marzo de 1465.

52 Ibídem, núm. 28.718: 10 de marzo de 1465. Relacionado con esta actividad alfarera, se ha encontrado una referencia de finales del siglo XV a una tejería (ARV, Mestre Racional, núm. 2.291).

53 Durante el siglo XV es citado con una relativa frecuencia en la documentación: ARCSCCV, Protocolos, Pere Vicent, núm. 24.258: 28 de enero de 1425; 29 de abril de 1425; 23 de julio de 1425. ARV, Mestre Racional, núm. 9.262, fol. 7r.

54 ARCSCCV, Protocolos, Pere Vicent, núm. 24.258: 5 de agosto de 1425.

55 Ibídem, núm. 24.258: 26 de agosto de 1425.

56 Ibídem, núm. 24.258: 20 de enero de 1425 (mencionando un documento del 20 de junio de 1392), 20 de enero de 1425 (mencionando un documento del 8 de mayo de 1398), 30 de marzo de 1425, 27 de agosto de 1425 .

57 Ibídem, núm. 24.258: 30 de marzo de 1425.

58 Ibídem, núm. 24.258: 29 de enero de 1425. 
acequia. Se ha conservado en sus proximidades el llamado Molino de la Villa, documentado desde el momento de la conquista cristiana (Eslava, 2014: 251253) y conocido a mediados del siglo XIV como molendenium vetus..$^{59}$ En la margen izquierda del río Ebrón, enfrente de la Barrera y la Serna, se encuentra el Sabuco, ${ }^{60} \mathrm{y}$, más arriba, la Plana ${ }^{61}$. Colindante a ambas partidas estaba la Carrera Teruel, ${ }^{62}$ nombre que proviene de la existencia del camino hacia Teruel por Villel en ese paraje, quedando descartadas otras interpretaciones sobre este topónimo (Gargallo, 2004: 51).

Siguiendo el cauce del río Ebrón hacia el sur, una vez pasada la villa de Castielfabib, se encuentra, en la margen derecha, la Rambla de la Fuent de la Solana ${ }^{63}$ un curso de agua que llega a la Fuente de la Solana - lugar de aprovisionamiento de agua para los vecinos de la población hasta la subida de agua corriente a la villa a mediados del siglo Xx-y que se conoce en la actualidad como Regajo. En las proximidades de esta fuente se encontraba el Prado la Fuent. ${ }^{64}$ Junto a la Fuent de la Solana, y paralela al río Ebrón se extiende la partida llamada la Vega Saragoça (también escrita Çaragoça o Çaragosa) ${ }^{65}$ en su primera referencia localizada en un documento de reparación de acequias es nombrada como pago nuncupati de Saragoça ${ }^{66}$ En una esquina delimitada por la Vega Saragoça y el río Ebrón se encuentra la Somida ${ }^{67}$ Enfrente de la Vega Saragoça, en la margen izquierda del río Ebrón se encuentra la esgleya de Sant Guillem (Eslava, 2014: 93), un templo que fue convento de antoninos a mediados del siglo $\mathrm{XIV}^{68}$ y a finales de dicha centuria albergó la primera casa de los agustinos en la villa de Castielfabib; posteriormente, quizá desde finales del si-

59 ACA, Cancillería, Registros, núm. 1198, fol. 222r.

60 ARCSCCV, Protocolos, Pere Vicent, núm. 24.258: 1 de octubre de 1425; 15 de octubre de 1425.

61 Ibídem, núm. 24.258: 17 de abril de 1425.

62 Ibídem, núm. 24.258: 30 de marzo de 1425. Actualmente, esta partida es llamada Carrateruel.

63 ARCSCCV, Protocolos, Pere Vicent, núm. 28.718: julio de 1465.

64 Ibídem.

65 Ibídem, núm. 28.718: diciembre de 1465. Ibídem, núm. 24.259: 29 de septiembre de 1468; 26 de diciembre de 1467; 10 de septiembre de 1469. Actualmente, la parte de Saragoça se ha normalizado en Zaragoza, siendo conocida como la Vega Zaragoza, o, a veces, se utiliza el genitivo en vez de la aposición, siendo denominada como la Vega de Zaragoza.

66 ACA, Real Cancillería, Cartas Reales, Pedro III [IV], núm. 393 (26 de julio de 1337). Existe una edición crítica de este documento, así como un breve estudio: Martínez Bedmar, 2019b: 13-18; 23-24; 28.

67 ARCSCCV, Protocolos, Pere Vicent, núm. 28.718: 17 de agosto de 1465. Actualmente, es conocida como la Sumida. Ibídem, núm. 24.259: 24 de junio de 1469; y 27 de agosto de 1470.

68 Es muy factible que este primer convento de mediados del siglo XIV llevara a cabo funciones asistenciales, funcionando como un hospital, ya que es bien sabido la atención que ejercían los antoninos contra la enfermedad del fuego infernal, ignis infernalis o fuego de san Antonio, que corresponde con el ergotismo (Conejo 2002: 114-115). 


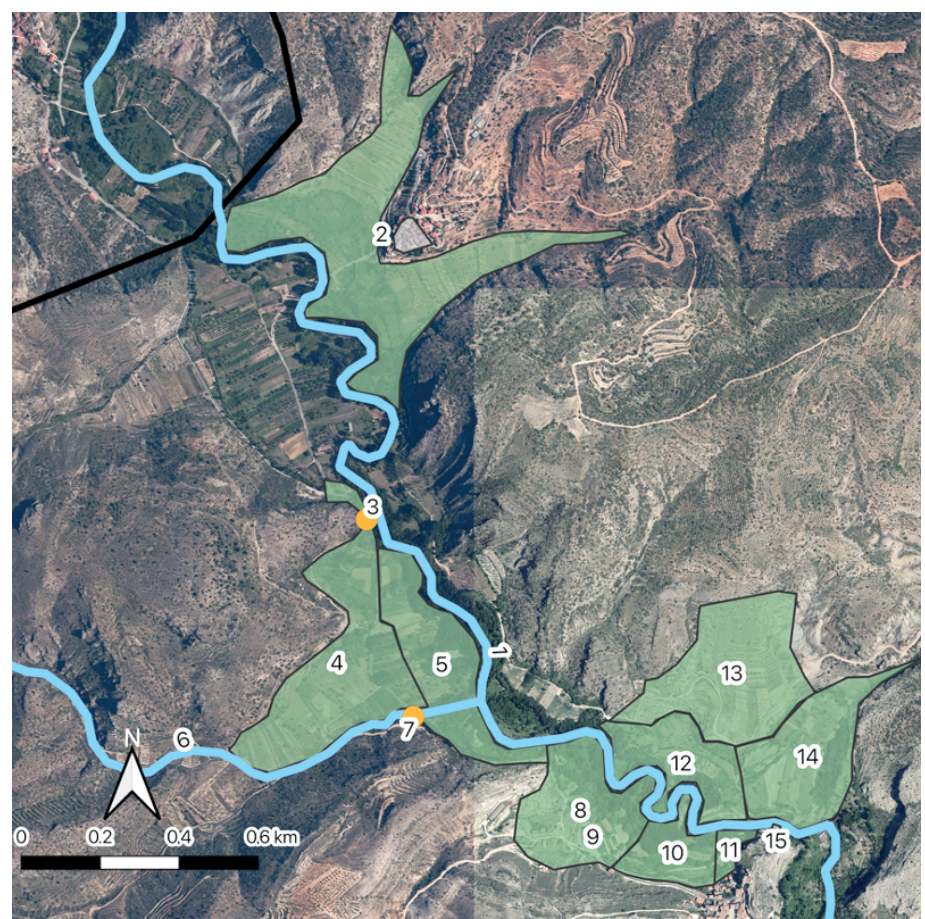

Mapa 5: Ubicación de partidas y lugares del curso alto del río Ebrón. 1: El Río; 2: La Cuesta del Rato; 3: La Penya de las Canales; 4: La Penya Negra; 5: La Vega Somera; 6: Vallis de la Salobre; 7: Pontis et canalis vallis de la Salobre / la puent de la Salobre; 8: La Barrera / la Ollería; 9: Monasterii beati Augustini; 10: La Serna; 11: El Chorreadero; 12: El Sabuco; 13: La Plana; 14: Carrera Teruel; 15: Molendenium vetus. Elaboración propia.

glo XV pasó a ser cenobio de carmelitas, que lo abandonaron a mediados del siglo XVI, dejando paso a los franciscanos que lo ocuparon las siguientes tres centurias (Eslava, 2002: 18 y 22; Eslava, 2014: 92-93 y 113-156).

Al suroeste de la Vega Saragoça se extiende la partida de los Planos, ${ }^{69}$ también conocida como orta dicte ville inferius, ${ }^{70}$ y se sabe que estaba recorrida por una acequia. La parte más baja de esta partida es referenciada en la documentación como el Fondón de los Planos. ${ }^{71}$

69 Ibídem, núm. 24.258: 24 de agosto de 1425.

70 Ibidem.

71 Ibídem, núm. 24.259: 19 de mayo de 1468. 


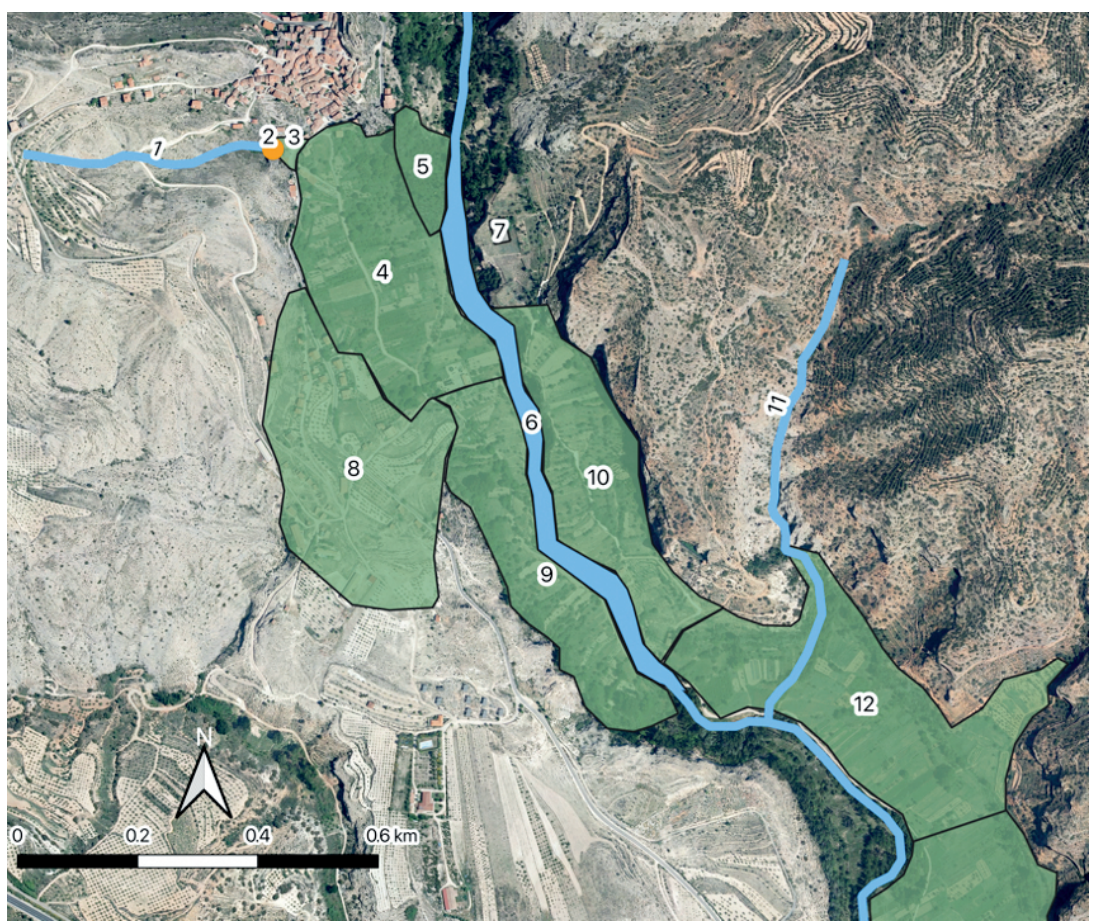

Mapa 6: Ubicación de partidas y lugares del curso medio del río Ebrón. 1: Rambla de la Fuent de la Solana; 2: Fuent de la Solana; 3: Prado la Fuent; 4: Vega Saragoça; 5: La Somida; 6: La Foz del Río; 7: Esgleya de Sant Guillem; 8: Los Planos; 9: El Toscar; 10: El Hituelo; 11: Varranquo de Jayme Pere; 12: El Molino Quemado. Elaboración propia.

Siguiendo el cauce del río Ebrón, en la margen derecha se encuentra el Toscar, ${ }^{72}$ actualmente denominado los Toscares. En un momento inicial debió conformar una gran partida que también incluyó la otra ribera del río, conocida como el Hituelo ${ }^{73}$ Entre ambas tierras, el río Ebrón discurre encajonado en una garganta citada en época medieval como la Foz del Río ${ }^{74}$ el topónimo ha experimentado un proceso de pluralización —al igual que el Toscar - y hoy es denominado Las Hoces.

72 Ibídem, núm. 24.258:9 de julio de 1425.

73 Ibidem. El documento dice «[...] quadam vineam nostram, francham sitam in orta dicte ville in partita vocata el Toscar, ad partem del Hituelo [...]».

74 ARCSCCV, Protocolos, Pere Vicent, núm. 24.258: 9 de julio de 1425. 
En la margen izquierda del río Ebrón, al sur del Hituelo, se encuentra la partida llamada el Molino Quemado, ${ }^{75}$ topónimo que delata la presencia de una instalación hidráulica destinada a la molienda, o quizá se tratase de un molino batán. Este paraje se encuentra atravesado por el Varranquo de Jayme Pere ${ }^{76}$ conocido en nuestros días como barranco del Escribano.

Al sur del Molino Quemado, en la misma margen izquierda, se encuentra la partida de la Penya Ruvia ${ }^{77}$ que concentraba parcelas destinadas al cultivo de la vid. Aguas abajo de esta partida, delimitada por el río Ebrón y por el antiguo camino a Torrebaja, se ubica el campo de Carrera la Torre ${ }^{78}$ cuyo nombre deriva de la vía que conducía hacia la dicha alquería.

Enfrente de las partidas de la Penya Ruvia y Carrera la Torre, en la margen derecha del río Ebrón, se halla Carrerademuz ${ }^{79}$ topónimo que indica, al igual que en los casos de Carrera Teruel y Carrera la Torre, la existencia en este punto del antiguo camino hacia la vecina Ademuz; morfológicamente, el topónimo ha contraído la última vocal de carrera con la primera de Ademuz.

Volviendo a la margen izquierda, se encuentra el topónimo de Los Sanctos, ${ }^{80}$ que hoy en día, igual que en el caso de la Cuesta del Rato, no designa una parte del término sino una aldea; quizá este espacio contase en su origen con alguna casa aislada o pequeña agrupación de viviendas destinada a habitación de los trabajadores de esta partida. Continuando por la misma margen, creemos poder ubicar la partida de la Casa de Vicent Marín ${ }^{81}$ topónimo no conservado en la actualidad; no obstante, la información suministrada por los documentos estudiados permite deducir una posible ubicación en esta zona en la

75 Ibídem, núm. 24.258: 3 de enero de 1425. Ibídem, núm. 24.259: 30 de enero de 1469.

76 Ibídem, núm. 24.258: 3 de enero de 1425. En el documento, se indican los límites de una viña sita en la partida del Molino Quemado: «[...] quandam vineam meam franquam sitam in partita vocata el Molino Quemado confrontatam cum via publica, cum Varranquo de Jayme Pere, et cum monte».

77 ACA, Real Cancillería, Registros, núm. 1.197, fol. 191v (3 de junio de 1364). ARCSCCV, Protocolos, Pere Vicent, núm. 24.258: documentos fechados el 20 de enero de 1425 (que mencionan otros datados en años anteriores: uno de 30 de enero de 1387; otro de 17 de abril de 1411 y otro de 20 de junio de 1392); y 7 de octubre de 1425. Ibídem, núm. 24.259: 26 y 29 de septiembre de 1468. Actualmente, es común leer los términos unidos: Peñarrubia.

78 Ibídem, núm. 24.258: 2 de abril y 20 de junio de 1425. Ibídem, núm. 24.259: 29 de septiembre de 1468. Actualmente su nombre se ha contraído: Calatorre.

79 Ibídem, núm. 24.258: 10 y 19 de abril de 1425; Ibídem, núm. 24.259: 26 y 29 de septiembre de 1468. Actualmente, este topónimo se ha contraído: Carrademuz.

80 Ibídem, núm. 24.258: 9 de abril de 1425.

81 Ibídem, núm. 24.258: 7 de enero de 1425. Ibídem, núm. 28.718: 7 de febrero de 1465. Ibídem, núm. 24.259: 24 de junio de 1468 . 


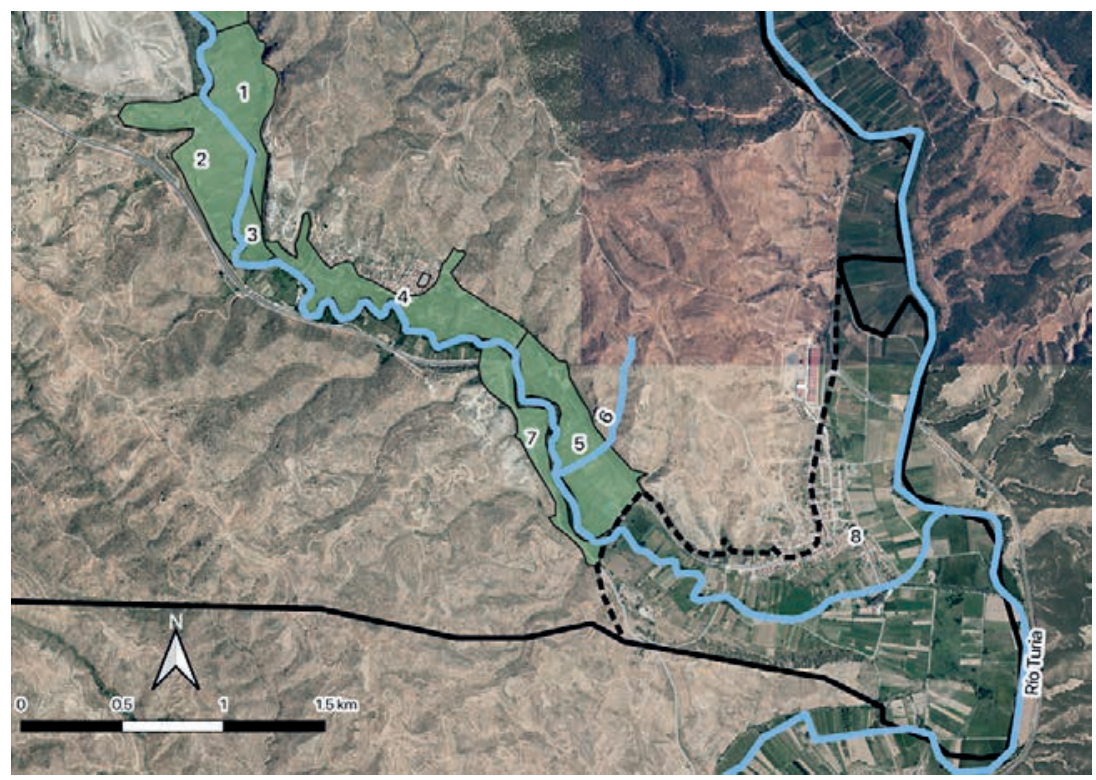

Mapa 7: Ubicación de partidas y lugares del curso bajo del río Ebrón. 1: Penya Ruvia; 2: Carrerademuz; 3; Carrera la Torre; 4: Los Sanctos; 5: Casa Vicent Marín (supuestamente); 6: Varranquo Vicent Marín (supuestamente); 7: Savina Gorda; 8: señorío de Torrebaja. Elaboración propia.

que también se han hallado nombres de otros accidentes geográficos relacionados con Casa de Vicent Marín: el Varranquo Vicent Marín ${ }^{82}$ — que debe corresponderse con el único barranco que atraviesa esa porción de tierra-y el Pozo Vicent Marín ${ }^{83}$, de momento sin identificar. En la otra ribera del Ebrón, enfrentada a la Casa de Vicent Marín, se encuentra la partida de la Savina Gorda. ${ }^{84}$

Por último, en el tramo final del río Ebrón, en una gran llanura destinada al regadío, se extiende el señorío de Torrebaja. Este señorío es conocido desde el primer tercio del siglo XIV, cuando se nombra el loco vocato Torre Fondonera, ${ }^{85}$ y se hace referencia a una de sus pobladoras, una sarracena (Eslava, 2012: 4-14). El lugar también es conocido como alquaream de la Torre Fondonera

82 Ibídem, núm. 24.259: 29 de septiembre de 1468.

83 Ibídem.

84 ARCSCCV, Protocolos, Pere Vicent, núm. 24.258: 7 de enero de 1425.

85 ACA, Real Cancillería, Cartas Reales, Alfonso III [IV], núm. 1130. 
(o alcharea $)^{86}$ o simplemente Torre Fondonera ${ }^{87}$ Su población era musulmana, apareciendo como habitantes de la alquería Yuce Zeyt y Abdalla Culeymen. ${ }^{88}$ En paralelo a este nombre de la Torre Fondonera, aparece ligado el topónimo el Villar d'Orchet: ${ }^{89}$ el término villar hace referencia a un asentamiento pequeño, una aldea o, como refiere la propia documentación, una alquería. Si el nombre de Torre Fondonera parece que convivió con el del Villar d'Orchet durante siglo y medio, hacia finales del siglo XV, en 1489, se han documentado más variantes de este nombre: Torre Jusana ${ }^{90}$ y Torre Baxa,${ }^{91}$ primera mención localizada del actual topónimo en un conjunto de nomenclaturas en el que tanto Fondonera como Jusana y Baxa se utilizaron sinónimos, como parece suceder en la misma cronología en otros territorios turolenses y zaragozanos. ${ }^{92}$

\section{La villa}

La villa de Castielfabib se ubica en el tramo central del Ebrón dentro del término de la misma, en un promontorio rocoso ubicado sobre un acusado meandro del río. Su primera ubicación fue la conocida como la Villa Vieya o la Vila Veya,${ }^{93}$ al norte de la Esgleya Mayor, ${ }^{94}$ actual templo de Nuestra Señora de los Ángeles, parroquia de la villa, adosada al castillo y situada en la cuarta planta de una de sus torres. Se ubicaba en un lugar central ya que tiene la función de comunicar la Villa Vieya con la Villa Nueva, donde actualmente se asienta la población. La Villa Vieya se sabe que estuvo habitada, al menos, hasta finales del siglo XIV. Del castillo se conserva diversa documentación; ${ }^{95}$ sin embargo, resulta

86 ARCSCCV, Protocolos, Pere Vicent, núm. 24.258: 20 de junio de 1425; 23 de septiembre de 1425.

87 Ibídem, núm. 24.258: 23 de julio de 1425. Ibídem, núm. 24.259: 24 de junio de 1468 .

88 Ibidem, núm. 24.258: 20 de junio de 1425.

89 Ibídem, núm. 24.258: 23 de julio de 1425; 23 de septiembre de 1425. AHPT, Concejo, Pergamino Ca, 8, 266 (7 de enero de 1489).

90 AHPT, Concejo, Pergamino Ca, 8, 266 (7 de enero de 1489).

91 Ibidem.

92 En la ciudad de Daroca también se observa el uso de dichos sinónimos para referirse a la Puerta Baja, Fondonera o Iusana (Rodrigo 1999); de modo parecido también se puede ver en los nombres de las barcas del Ebro, donde hay Iusana, Susana o Baja (Mullor 2007); y también en nombres de localidades turolenses como Formich Susano y Formich Iusano (Formiche Alto y Formiche Bajo), y Villalva la Susana y Villalva la Iusana (Villalba Alta y Villaba Baja) (Falcón 1983).

93 ACA, Real Cancillería, Registros, núm. 1385, fol. 79r-v (11 de febrero de 1363).

94 Ibidem.

95 ACA, Real Patrimonio, Maestre Racional, Volúmenes, Serie General, núm. 2.420. ARV, Mestre Racional, núm. 9.262; $2.283 ; 2.288 ; 2.291$. 
difícil relacionar los espacios conservados con aquellos referenciados en las fuentes archivísticas medievales, ya que el mismo edificio fue objeto de continuas reformas y transformaciones durante el período bajomedieval, a comienzos de la Edad Moderna, y, finalmente, durante la Primera Guerra Carlista, desdibujando en buena medida - y a falta de nuevos estudios documentales, arqueológicos y arquitectónicos - , la fisionomía de esta fortaleza en sus orígenes.

La Villa Nueva se encontraba amurallada, según se documenta desde, al menos, 1337 - muris dicte ville — $;{ }^{96} \sin$ embargo, el primitivo recinto murado debió ser anterior y en continua reforma y ampliación, además de verse sometido a reparaciones debido a las guerras del siglo XIV, y a las necesidades de una población en crecimiento y consolidación en el tránsito entre el periodo medieval y la modernidad. Se conoce la existencia de dos portales en época medieval: la Portam Ferream ${ }^{97}$ o 'Puerta Férrea', ubicada a poniente de la villa, en el camino a Castilla y, por tanto, en un enclave que requería estar sólidamente fortificado. ${ }^{98}$ También se tiene noticia del Portal de la Vila, ${ }^{99}$ que debió constituir el principal acceso a la villa y se puede identificar con el actual El Portal, ubicado al sur del plano urbano y donde a día de hoy se conserva un pasaje cubierto. Sin embargo, aunque no mencionados en las fuentes documentales consultas, debieron existir más accesos a la población, por el flanco norte, por la parte de la Villa Vieya, y por el camino hacia Teruel, y por poniente también debió existir algún portal hacia la vecina población de El Cuervo, ya en el reino de Aragón.

Por lo que respecta a la configuración urbana interna de la villa de Castielfabib, se debe decir que esta no estaba, ni está, configurada por calles rectilíneas, sino por vías sinuosas que no siguen un trazado claro, y que se configuran más bien en barrios, y así es como se encuentra en la documentación medieval, siendo frecuente la mención de vico o varrio en las fuentes utilizadas. Por el norte, el primer barrio es el Varrio de Yuso, ${ }^{100}$ nombre probable-

96 ACA, Real Cancillería, Cartas Reales, Pedro III [IV], núm. 425 (4 de septiembre de 1337).

97 ARCSCCV, Protocolos, Pere Vicent, núm. 24.258: 24 de agosto de 1425.

98 En esta parte, aunque no documentadas directamente en época medieval, persisten diversas torres que debieron formar parte del cinturón defensivo de la villa de Castielfabib, como la Torreta - que constituía una fortaleza en sí misma - , la Torre Almenada - que debió formar parte del conjunto defensivo de la Puerta Férrea-, y más al sur, el Torrejón, otro acceso en el recinto murado que permitiría una salida directa a la huerta sur, esto es, a la Vega Saragoça y otras partidas.

99 ARV, Mestre Racional, núm. 9.262, fols. 19r; 20v.

100 ARCSCCV, Protocolos, Pere Vicent, núm. 24.258: 20 de enero, 9 de abril, 30 de septiembre, 7 de octubre y 5 de noviembre de 1425; Ibídem, núm. 28.718: 17 de agosto de 1465 
mente relacionado a encontrarse por debajo de la iglesia parroquial y los barrios más antiguos, que ha evolucionado hasta el actual Barrioso, enmascarando su origen toponímico. Relacionado con esta parte de la villa, aparece el nombre açuqaquo ${ }^{101}$ (también escrito como açuquaco ${ }^{102} \mathrm{o}$ açuquaco), ${ }^{103}$ que proviene de la voz valenciana 'atzucac', con significado de calle sin salida, siendo un hecho bastante frecuente en el urbanismo castielero. Por encima de este, se encuentra el barrio del Callicio, ${ }^{104}$ que aún dispone un trazado que se asemeja más a una calle, pudiendo responder a una de las primeras ampliaciones del recinto amurallado; el topónimo corresponde con la palabra catalana callís, que según el Diccionari Català Valencià Balear tiene por significado un camino entre muros o hileras de árboles, pudiéndose relacionar con la salida e inicio del camino hacia El Cuervo.

En el centro de la población se encuentra la Plaça de la Villa ${ }^{105}$ documentada desde finales del primer tercio del siglo XIV. Conocida también como Plaça Comuna ${ }^{106}$ era el centro neurálgico de la localidad donde se ubicaba la sede de la municipalidad en la Casa Comuna de la Villa.

Al sur de la villa se encontraba el barrio de La Solana ${ }^{107}$ en alusión a su posición en pendiente y orientada a mediodía. Sin embargo, a pesar de que este topónimo se conserva, parece ser que se ha desplazado hacia el sur, pues actualmente el espacio conocido como la Solana corresponde a una zona extramuros, quizá relacionada con el denominado Fondón de la Solana, ${ }^{108}$ la parte más baja de esta pendiente orientada al sur y donde se ha documentado la presencia de construcciones agrícolas como pajares.

También ha aparecido una referencia al vico vocato la Cueva, ${ }^{109}$ topónimo que no se ha conservado hasta nuestros días; podría corresponder a la parte sur del recinto amurallado más próxima al castillo, donde existen algunas cuevas

101 Ibídem, núm. 24.258: 26 de febrero de 1425.

102 Ibídem, núm. 24.258: 26 de septiembre de 1425.

103 Ibídem, núm. 24.258: 7 de octubre de 1425.

104 Ibídem, núm. 24.258: 10 de enero, 10 de abril y 19 de junio de 1425. Actualmente, la denominación ha evolucionado hacia el Calicio.

105 ACA, Real Cancillería, Pergaminos, Alfonso III [IV], núm. 410 (1329); ARCSCCV, Protocolos, Pere Vicent, núm. 24.258: 14 de enero, 30 de marzo, 16 de julio, 26 de septiembre, 10, 22 y 23 de octubre de 1425 .

106 ARCSCCV, Protocolos, Pere Vicent, núm. 24.258: 23 de octubre de 1425

107 Ibídem, núm. 24.258: 1 de octubre de 1425.

108 Ibídem, núm. 24.259: 30 de julio de 1468 y 3 de febrero de 1469.

109 Ibídem, núm. 24.258: 16 de noviembre de 1425. 
excavadas en la roca de la fortaleza. Además, hay que indicar que las áreas no mencionadas en la documentación del siglo XV corresponden a los barrios más antiguos, que presumiblemente eran los más consolidados en esa época, y por lo tanto, con menos movimientos de compraventa registrados ante notario, lo que justificaría la no localización documental de dichos topónimos (VázquezEsparza, 2014: 222-228).

Intramuros de la población se ubicaba la heremita de Sent Blay, ${ }^{110}$ documentada únicamente durante la segunda mitad del siglo XV. Se desconoce su localización precisa. Sin embargo, debió gozar de una cierta popularidad, importancia y antigüedad por albergar el beneficio de San Blas, hecho extraño en la comarca pues los templos no parroquiales no solían poseer capellanías (Eslava, 2014: 91-92).

En las proximidades de la villa se encontraba el Hospital de Pobres, ${ }^{111}$ fundado a mediados del siglo XV por la autoridad real y localizado en el camino hacia El Cuervo, extramuros, al final del barrio del Callicio.

Siguiendo este recorrido por el plano urbano de Castielfabib se deben mencionar aquellos lugares ligados a las necesidades más básicas de su población, entre los que se encuentran los hornos de cocer pan documentados desde principios del siglo XIV (Eslava, 2014: 199) aunque ya debieron existir en tiempos de los musulmanes. En la villa cristiana se documentan dos hornos: el Forno Somero, ${ }^{112}$ ubicado en la parte alta de la población, cerca de la Puerta Férrea; y el Forno Fondonero, ${ }^{113}$ localizado en la parte baja, en las cercanías de la Plaça de la Villa. También hay referencias durante toda la segunda mitad del siglo XV a les dues taules de carniceria, ${ }^{114}$ pero ignoramos su ubicación. La presencia de diversas bodegas se relaciona directamente con el cultivo de la vid documentado en el término de Castielfabib. ${ }^{115}$ Además, la actividad ganadera y el pastoreo ovino hay que relacionarlo con la presencia de diversos

110 ARV, Mestre Racional, núm. 9.262, fol. 22r.

111 ARV, Cancillería Real, Registros, núm. 269, fol. 56r (1 de julio de 1446). Aparece mencionado también en ARCSCCV, Protocolos, Pere Vicent, núm. 24.259): 29 de marzo de 1469.

112 ARCSCCV, Protocolos, Pere Vicent, núm. 24.258: 8 de enero de 1425; 24 de agosto de 1425. Ibídem, núm. 24.259: 1 de enero de 1468 .

113 Ibídem, núm. 24.258: 8 de enero de 1425. Ibídem, núm. 24.259: 1 de enero de 1468 .

114 ARV, Mestre Racional, núm. 2.282; 2.284; 2.285; 2.286; 2.287; 2.288; 2.289; 2.290; 2.291; 2.292; $2.293 ; 2.294 ; 2.295 ; 2.296 ; 2.297 ; 2.298 ; 2.299$.

115 ARCSCCV, Protocolos, Pere Vicent, núm. 24.258: 10 de enero de 1425; 3 de abril de 1425; 15 de octubre de 1425 . 
oficios: el parator pannorum — el pelaire que prepara la lana para tejerla_,${ }^{116}$ y el textor o tejedor, ${ }^{117}$ que manufacturaba el producto derivado de la lana; estos artesanos debieron contar con obradores propios, probablemente, en los bajos de sus viviendas. Otro oficio documentado es el de fustero o carpintero, que en 1425 ejercía Johan López; ${ }^{118}$ debió disponer también de taller en los bajos de su casa y su trabajo estaría destinado a cubrir las necesidades de la población local pues sólo se ha documentado un único obrador y no varios como en el caso de los oficios de la lana. En relación con la producción industrial se localizan los espacios conocidos como lo Pla de la Calera, ${ }^{119}$ — para la extracción de la cal, muy importante en la arquitectura vernácula de la comarca-, y la Pedrera de la dita vila, ${ }^{120}$ es decir, la cantera donde se extraía la piedra, también importante para la construcción. A pesar de la importancia que estos espacios tuvieron en época medieval, en la actualidad se desconoce su ubicación exacta.

Finalmente, se debe tratar la Casa Comuna de la Villa, el edificio que presidió la Plaça de la Villa y sigue haciéndolo hoy en día pues se identifica con la actual Casa de la Villa. Se trataba de un edificio de dos plantas: la superior, conocida como Cambra del Consell, ${ }^{121}$ recibe diversos nombres: Aula Comuni, ${ }^{122}$ Camera Curie ville Castri Habib, ${ }^{123}$ Camera seu Sala Comuni ${ }^{124}$ o Sala Comuna de la villa de Castielhabib. ${ }^{125}$ Este espacio era utilizado como lugar de reunión del consejo municipal y en él se impartía justicia siendo, por lo tanto, un espacio especialmente representativo del poder de la villa en épo-

116 En el año 1425 se documentan los pelaires Johannes Sarçuela (ARCSCCV, Protocolos, Pere Vicent, núm. 24.258, doc. 7 de enero), Johannes Soriano (ibíd., 15 de enero), Anthonius Sánchez (ibíd., 5 de abril) y Dominicus Peydró (ibíd., 11 de abril).

117 En el año 1425 se documentan los tejedores Petrus Garsie y Johannes Garsie (ARCSCCV, Protocolos, Pere Vicent, núm. 24.258: 7 de enero), Johannes Sanccii (ibíd., 23 de enero), Miquael Sanccii y Dominicus Garsie (ibíd., 26 de febrero), Miquael de Sisamón (ibíd., 9 de abril), Dominicus Ruvio, menor (ibíd., 25 de septiembre) y Martinus Gómez (ibíd.,14 de noviembre).

118 ARCSCCV, Protocolos, Pere Vicent, núm. 24.258: 18 de enero de 1425. El carpintero además realizaría labores de construcción, aunque también se han identificado algún maestro de obras vinculado a trabajos de reforma realizados en el castillo de la villa (García 2003: 7-15; López y García 2012: 115).

119 ARV, Mestre Racional, núm. 2.283, fol. 2v.

120 Ibídem, núm. 2.284, fol. 19v.

121 Ibídem, núm. 9.262, fol. 25r.

122 ARCSCCV, Protocolos, Pere Vicent, núm. 24.258: 3 de junio, 7 de octubre y 9 de noviembre de 1425; Ibídem, núm. 28.718: 26 de marzo de 1465 (simplemente como Aula).

123 Ibídem, núm. 24.258: 29 de enero de 1425.

124 Ibídem, núm. 24.258: 28 de octubre de 1425.

125 Ibídem, núm. 28.718: 4 de febrero de 1465. 


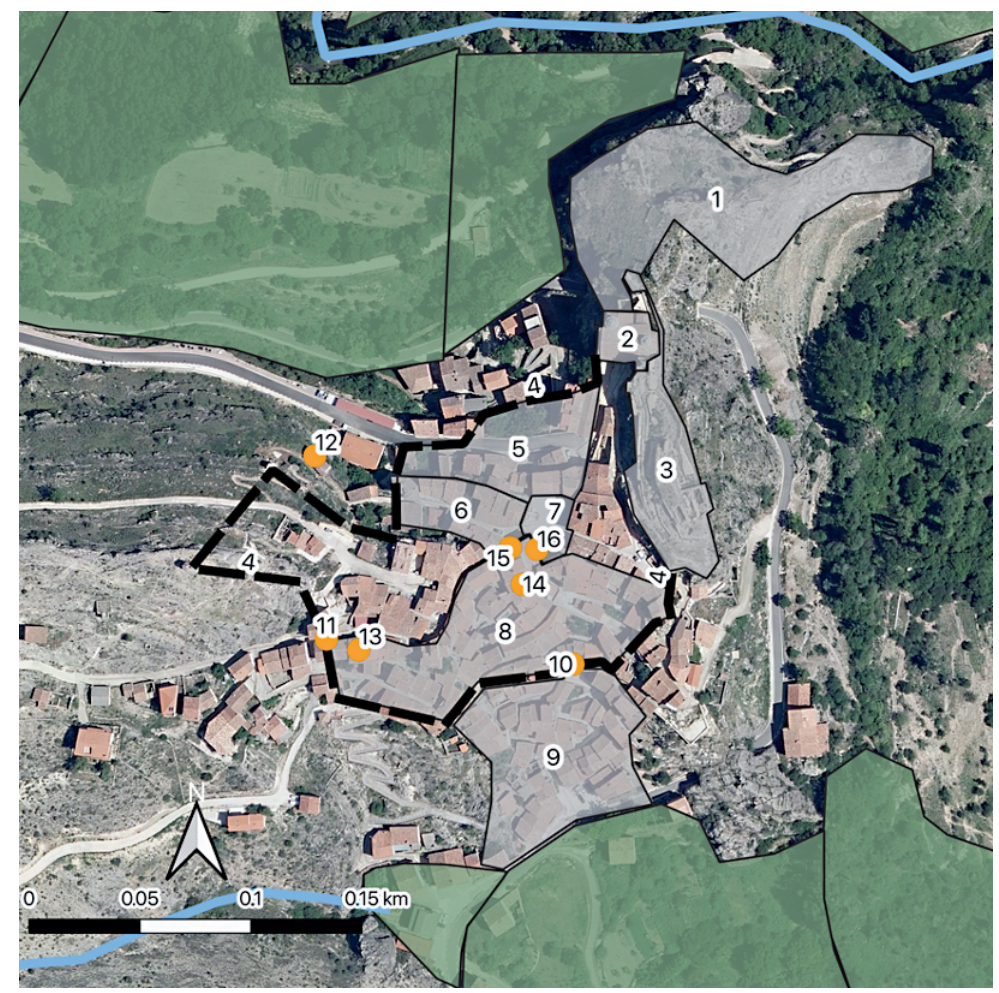

Mapa 8: Ubicación de barrios, espacios y lugares de la villa de Castielfabib. 1: la Villa Vieya; 2: Esgleya Mayor; 3: Castillo; 4: Muris dicte Ville; 5: Varrio de Yuso; 6: El Callicio; 7: Plaça de la Villa; 8: La Solana; 9: El Fondón de la Solana; 10: Portal de la Vila; 11: Portam Ferream; 12: Ospitali dicte Ville; 13: Forno Somero; 14: Forno Fondonero; 15: Presón comuna de la dicha Villa; 16: Casa comuna de la villa de Castielfabib. Elaboración propia.

ca foral. En la planta baja se encontraba el Porche de la Casa Comuna, ${ }^{126}$ que remite a la existencia de un espacio porticado abierto hacia la Plaça de la Vi$l l a$, y que era utilizado para las mismas funciones que la cámara del piso superior, seguramente durante los meses en los que la climatología permitía celebrar fuera del edificio las reuniones y juicios. Los airosos arcos de este porche debieron estar limitados por una reja, como se deduce de la documentación donde se menciona el rexado de la cort de la villa de Castielhabib. ${ }^{127}$ Este

126 Ibídem, núm. 24.258: 1 de agosto de 1425; y 30 de mayo de 1425 (nombrado como Portico Curie).

127 Ibídem, núm. 24.258: 17 de agosto de 1425. 
porche debió ejercer una función de distribuidor al dar acceso, probablemente, al piso superior, esto es, a la Cambra del Consell, y también a la prisión de la villa, ya que se menciona el porche de la presón o casa comuna. ${ }^{128}$ Detrás de la Casa Comuna - donde aún se conserva aunque presumiblemente transformado- se debía hallar este espacio carcelario citado como la presón comuna de la dicha villa. ${ }^{129}$

\section{Conclusiones}

Los topónimos que se han localizado en la documentación escrita consultada responden principalmente a características del terreno y de su ubicación: la Nava, la Penya Negra, la Vega Somera, la Barrera (o la Ollería), la Serna, el Chorreadero, la Plana, Carrera Teruel, los Planos, el Toscar, la Foz del Río, el Molino Quemado, la Penya Ruvia, Carrerademuz, Carrera la Torre, la Savina Gorda, la Torre Fondonera (o la Torre Jusana o la Torre Baxa) el Varrio de Yuso, el Callicio, la Plaça de la Villa y la Solana, entre otros. También se utilizaron topónimos derivados de nombres propios - por ejemplo, los derivados de Vicent Marín, Casa, Varranquo y Pozo; el Varranquo de Jayme Pere y el Varranquo de Johan de Yerme. Finalmente, otros topónimos muestran un origen dudoso; es el caso del río Dronio, el río de Molas, el Royo del Cereso, la Cuesta del Rato, el Sabuco, la Vega Saragoça, el Hituelo, los Sanctos y el Villar d'Orchet.

En cuanto al hábitat, el sector occidental del núcleo - la zona del Royo del Cereso - , presenta una distribución dispersa, apareciendo en la documentación la figura del mas o mansum, voz que designa grandes explotaciones agroganaderas de secano y en esta zona incluye también el aprovechamiento maderero que se benefició de las rutas fluviales para su comercialización en Valencia. En el eje del río Ebrón, en la parte central del término, se alza la villa, con un dominio visual de todo el curso fluvial gracias a su localización y a la de sus atalayas ubicadas en el Castillo y la Torreta. A pesar de las crisis bajomedievales, la villa alcanzó un notable grado de desarrollo en época tardomedieval, mostrándose como un lugar dinámico y capaz de generar riqueza en medio de estas tierras de frontera. El eje del río Ebrón contó, muy probablemente, con diversas unidades de poblamiento al margen de la villa rectora 
de Castielfabib: al norte, la Cuesta del Rato; al sur, Los Sanctos; y en el tramo final del curso del Ebrón, la alquería de la Torre Fondonera. Con esta distribución espacial del poblamiento se consiguió una explotación más racional y eficaz del territorio, en especial, de las tierras de regadío.

Aunque es prácticamente nula la información sobre las parcelas y lugares habitados en el eje del río Turia, es factible la existencia de grandes explotaciones de regadío vinculadas a masos o mases, de la forma que hemos constatado en la parte occidental del término; estos enclaves habitados bien pudieron ser los embriones de las actuales aldeas del Mas de Jacinto y el Mas de los Mudos y reproducir en su territorio el modelo de explotación agraria documentado en el Ebrón, con una serie de pequeños núcleos poblacionales a lo largo del eje norte-sur del río, distanciados de manera regular para un mejor aprovechamiento y trabajo de las tierras: el Mas de Jacinto, en la margen derecha; la Torre Alta, en la ribera izquierda; y el Mas de los Mudos y la Torrebaja, ambos en la ribera derecha.

Las tierras de poniente de Castielfabib estuvieron ocupadas por grandes bosques; su producción maderera permitió la exportación y abasteció a la ciudad de Valencia y a otros lugares a través del transporte fluvial, constituyendo una importante fuente de ingresos y de empleo. Además, en la parte media del término concejil se extendieron las explotaciones de secano dedicadas al cereal; su producción no logró cubrir la demanda local, haciéndose necesaria la importación de grano proveniente del vecino reino de Aragón. Otra fuente de ingresos fue la ganadería caprina y ovina — que debió de abastecer de materia prima a los pelaires y tejedores locales que se han documentado-; al igual que con la madera, los productos excedentarios primarios o manufacturados en Castielfabib satisficieron la demanda del mercado valenciano. Además, el oficio de ollero ha quedado bien documentado y se ha localizado un espacio propio para la fabricación de obra de tierra en las proximidades de la villa; también se ha obtenido información sobre una tejería, una cantera y una calera y un artesano de la madera, instalaciones y profesiones muy ligadas al sector de la construcción y del mantenimiento de edificios y del recinto murado.

La carestía de cereal, un problema endémico del Castielfabib medieval, obligó al cultivo de grano en el eje del río Ebrón, a pesar de ser un territorio de regadío riquísimo, con una huerta espléndida. También parte de este valle fluvial fue utilizado para la producción de vid, debiendo tener un peso importante en la economía local al haberse hallado numerosas bodegas en la villa. 
En cuanto al urbanismo de la villa de Castielfabib, el entramado urbano resulta complejo debido a su peculiar ubicación que dificulta el desarrollo de calles más o menos lineales. Por ello, la población se distribuye en barrios, habiendo encontrado referencias de cuatro - el Varrio de Yuso, el Callicio, la Solana y la Cueva -, además de la Plaça de la Villa. Resulta llamativo la ausencia de menciones archivísticas de la parte más antigua de la población; cabe la hipótesis de que fuese el ámbito poblacional más consolidado y con una menor fluctuación de la propiedad que en los barrios más modernos y dinámicos.

Para finalizar quiero destacar lo novedoso del análisis que se ha realizado sobre Castielfabib y su territorio. El estudio de la toponimia y microtoponimia documentada en fuentes escritas dispersas en diversos fondos archivísticos se ha complementado con el trabajo de campo realizado sobre fuentes materiales y fuentes orales. Y todo ello ha permitido reconstruir la sociotopografía de la villa, la antropización de su territorio y las interacciones con otros territorios durante el periodo bajomedieval y, en especial, durante el siglo XV. Los resultados alcanzados arrojan luz sobre esta villa de frontera y son parte de una investigación en curso más amplia, cronológicamente hablando, sobre la toponimia en la villa y término de Castielfabib.

\section{Referencias bibliográficas}

Alvira CABrer, Martín (2010), Pedro el Católico, Rey de Aragón y Conde de Barcelona (1196-1213). Documentos, Testimonios y Memoria Histórica, vol. III. Zaragoza, Institución Fernando El Católico.

ANDRÉS Robres, Fernando; Cruselles GómeZ, José María; RiBes TraVER, María Estrella; TolosA RoBledo, Lluïsa; VALLÉS BorRÁs, Vicent Joan (1990), Inventario de fondos notariales del Real Colegio Seminario de Corpus Christi de Valencia. Valencia, Generalitat Valenciana, Conselleria de Cultura, Educació i Ciència.

ANTÓN ANDRÉS, Ángel (2006): «Un topónimo enrevesado: Bohílgues», Ababol. Revista del Instituto Cultural y de Estudios del Rincón de Ademuz, 46: 11-20.

ARCINIEGA GARCÍA, Luís (2011), «El abastecimiento fluvial de madera al Reino de Valencia», en María del Carmen Poyato Holgado, Josep Montesinos Martínez (eds.), La Cruz de los Tres Reinos. Espacio y tiempo en un territorio de frontera. Cuenca, Ediciones de la Universidad de Castilla-La Mancha: 99-134.

CONEJO DA PENA, Antoni (2002), Assistència $i$ hospitalitat a l'edat mitjana. $L$ 'arquitectura dels hospitals catalans: del gòtic al primer renaixement (tesis doctoral). Barcelona, Universitat de Barcelona. 
CRuselles Gómez, José María (1998), Els notaris de la ciutat de València. Activitat profesional $i$ comportament social a la primera meitat del segle XV. Barcelona, Fundació Noguera.

ESLAVA BLASCO, Raúl (2002), «Reliquias y religiosidad popular en el Rincón de Ademuz (I): el cuerpo de san Guillén de Castielfabib», Ababol. Revista del Instituto Cultural y de Estudios del Rincón de Ademuz, 30: 15-25.

ESLAVA BLASCO, Raúl (2012), «El señorío de Torrealta y su iglesia parroquial», Ababol. Revista del Instituto Cultural y de Estudios del Rincón de Ademuz, 68: 4-14.

ESLAVA Blasco, Raúl (2014), Castielfabib y su patrimonio histórico-artístico. Castielfabib, Ayuntamiento de Castielfabib.

FALCÓN PÉREZ, María Isabel (1983): «Aportación al estudio de la población aragonesa a finales del siglo XV», Aragón en la Edad Media, 5: 255-302.

GARCÍA MARSILlA, Juan Vicente (2003): «Las obras que nunca se acaban. El mantenimiento de los castillos en la Valencia medieval: sus protagonistas y sus materiales», Ars Longa, Cuadernos de Arte, 12: 7-15.

GARGallo GIL, José Enrique (2004), Habla y cultura popular en el Rincón de Ademuz, Madrid, Consejo Superior de Investigaciones Científicas.

Gual Camarena, Miguel (1953), Precedentes de la reconquista valenciana. Valencia, Consejo Superior de Investigaciones Científicas, Instituto Valenciano de Estudios Históricos, Institución Alfonso el Magnánimo.

GUINOT RODRÍGUEZ, Enric (1995), Els límits del Regne. El procés de formación territorial del País Valencià medieval (1238-1500). Valencia, Edicions Alfons el Magnànim.

LEDESMA Rubio, María Luisa (1986), «La formación de un señorío templario y su organización económica y social: la encomienda de Villel», Príncipe de Viana. Anejo, 2-3: 441-462.

LÓPEZ GonzÁlez, María Concepción; GARCía VAlldECABRES, Jorge (2012), «Los orígenes de la iglesia-fortaleza de Castielfabib: análisis gráficos», EGA. Expresión Gráfica Arquitectónica, 20: 112-123.

MARTíNEZ BEDMAR, Alberto-Jesús (2018), «La conquista cristiana de los castillos de Castielfabib y Ademuz y su inclusión en el reino de Valencia (1210-1261)», Aragón en la Edad Media, 29: 139-164.

MARTÍNEZ BEDMAR, Alberto-Jesús (2019a), Edició crítica de tres documents relatius a la vila de Castellfabib (trabajo inédito). Barcelona, Universitat de Barcelona.

MARTínEZ BEDMAR, Alberto-Jesús (2019b), Edició crítica de quatre documents notarials de la vila de Castellfabib (trabajo inédito). Barcelona, Universitat de Barcelona.

MARTínEZ BEDMAR, Alberto-Jesús (2019c), Fitxa de la notaria de Castellfabib (documento inédito). Barcelona, Universitat de Barcelona.

MARTíNEZ BEDMAR, Alberto-Jesús (2020), «Nuevas consideraciones sobre el topónimo enrevesado del río Bohílgues», Ababol. Revista del Instituto Cultural y de Estudios del Rincón de Ademuz, (pendiente de publicación). 
Mileto, Camilla; Vegas López-Manzanares, Fernando (2008), Homo faber. Arquitectura preindustrial del Rincón de Ademuz. Casas Altas, Mancomunidad de Municipios del Rincón de Ademuz.

MUllor SANDOVAL, Rufina (2007): Al pasar la barca... Historias particulares de las barcas de paso en Aragón. Zaragoza, Institución «Fernando el Católico».

Rodrigo Estevan, María Luz (1999): La ciudad de Daroca a fines de la edad media. Selección documental (1328-1526). Daroca, Centro de Estudios Darocenses, Institución «Fernando el Católico».

RUEDA MurRiA, José (2001), «La vida en el Rincón de Ademuz en la Edad Media». Ababol. Revista del Instituto Cultural y de Estudios del Rincón de Ademuz, 27: 27-31.

VÁZQUEZ-ESPARZA, Álvaro (2014), Interpretando fragmentos. Trazado y análisis de un recinto amurallado de frontera: la Villa de Castielfabib, Valencia, Universitat Politècnica de València.

VÁZQUEZ-ESPARZA, Álvaro (2015), «La estructura defensiva del río Turia en la cabecera del territorio valenciano», Arché. Publicación del Instituto Universitario de Restauración del Patrimonio de la UPV, 10: 461-470. 